\title{
Relacja pacjent-płatnik-lekarz
}

\author{
Piotr Bromber
}

\begin{abstract}
Streszczenie: $\mathrm{Cel}-\mathrm{W}$ artykule zwrócono uwagę na znaczenie relacji między interesariuszami w ochronie zdrowia. Rozważania dotyczą relacji między pacjentem (świadczeniobiorcą), lekarzem (świadczeniodawcą) a płatnikiem trzeciej strony. Autor określił je mianem ,trójkąta relacji” w ochronie zdrowia.

Metodologia badania - Na potrzeby artykułu dokonano przeglądu literatury przedmiotu, badań opinii społecznej oraz skarg składanych przez pacjentów.

Oryginalność/wartość - Przedstawiono działania podejmowane przez Lubuski Oddział Wojewódzki Narodowego Funduszu Zdrowia (LOW NFZ) w zakresie kształtowania relacji.
\end{abstract}

Słowa kluczowe: relacje, zaufanie, pacjent, lekarz, NFZ

\section{Wprowadzenie}

Aktualnie w ochronie zdrowia zwiększa się nakłady finansowe i ustala nowe limity miejsc na studiach medycznych. Na różne sposoby analizuje się koszty. Implementuje się coraz to nowsze rozwiązania informatyczne. Próbuje się wykazywać prymat prywatnego sektora nad publicznym i odwrotnie. Dąży się do spersonalizowania i skoordynowania medycyny.

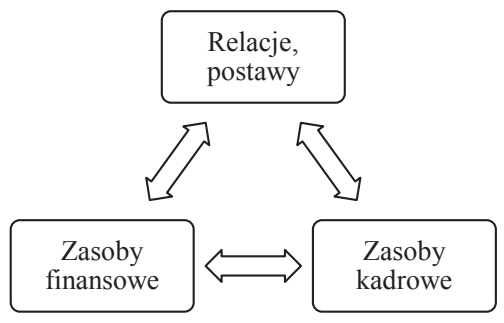

Rysunek 1. Trzy priorytety w ochronie zdrowia

Źródło: opracowanie własne.

W tym natłoku koncepcji i działań zapomina się, jak ważnym w ochronie zdrowia jest kształtowanie postaw i relacji między interesariuszami (relacje, postawy). Na problem

\footnotetext{
*mgr Piotr Bromber, Lubuski Oddział Wojewódzki Narodowego Funduszu Zdrowia, email: piotr.bromber@ nfz-zielonagora.pl.
} 
zwraca uwagę A. Ostrowska. Już kilkanaście lat temu pisała, że znacznie mniej uwagi poświęca się bezpośrednim relacjom między „dawcami” i „biorcami” usług medycznych (Ostrowska, 2006, s. 187). Znamienne jest, że w perspektywie ponad 10 lat społeczna uwaga koncentrująca się na ochronie zdrowia nadal zdominowana jest problematyką niedoborów, dzisiaj nie tylko niedoborów finansowych (zasoby finansowe), ale też brakującego personelu medycznego (zasoby kadrowe).

\section{Elementy skladowe „trójkąta relacji” w ochronie zdrowia}

Niniejsze rozważania dotyczą relacji między pacjentem (świadczeniobiorcą), lekarzem (świadczeniodawcą) a płatnikiem trzeciej strony. W tym zakresie wykorzystano metaforę trójkąta (Nowakowska, 2015, s. 286). Artykuł nie obejmuje bezpośrednich relacji pacjentlekarz'1.

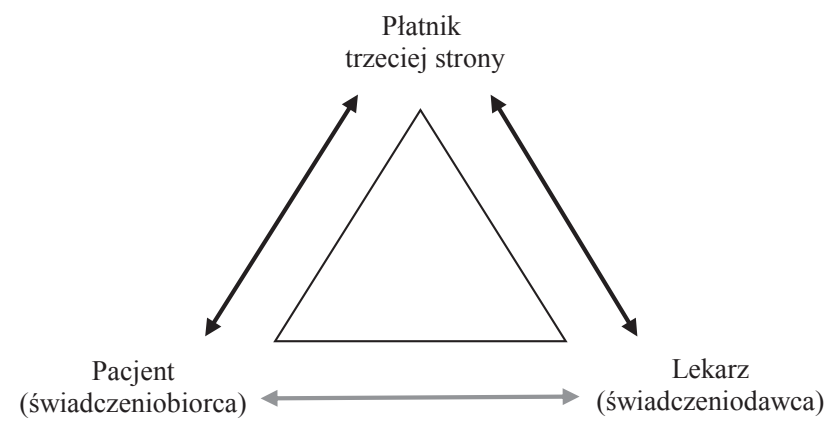

Rysunek 2. „Trójkąt relacji” w ochronie zdrowia

Źródło: opracowanie własne.

W Polsce funkcje płatnika trzeciej strony pełni NFZ. Zasady jego funkcjonowania, organizację i zakres działania określa ustawa o świadczeniach opieki zdrowotnej finansowanych ze środków publicznych (Ustawa, 2004).

\footnotetext{
${ }^{1}$ Szczegółowo omówionych w literaturze przedmiotu. Zob. M. Nowina-Konopka (2016). Komunikacja lekarz-pacjent. Teoria i praktyka. Kraków: Instytut Dziennikarstwa, Mediów i Komunikacji Społecznej Uniwersytet Jagielloński; A. Maciąg (2008). Komunikacja interpersonalna a jakość świadczeń zdrowotnych. Istota relacji lekarz-pacjent w medycynie. Studia i Materiaty WZ UW, 1; A. Maciąg (2011). Kulturowe uwarunkowania komunikacji interpersonalnej w relacjach lekarz-pacjent. Studies \& Proceedings of Polish Association for Knowledge Management, 55; I. Czerska (2016). Relacje lekarz-pacjent a wybrane teoretyczne modele relacji w kontekście dehumanizacji medycyny. Handel Wewnętrzny, 5; K. Szewczyk (2009). O bezsensie i potrzebie konstruowania modeli relacji lekarz-pacjent. Krytyka Lekarska, 2-3.
} 


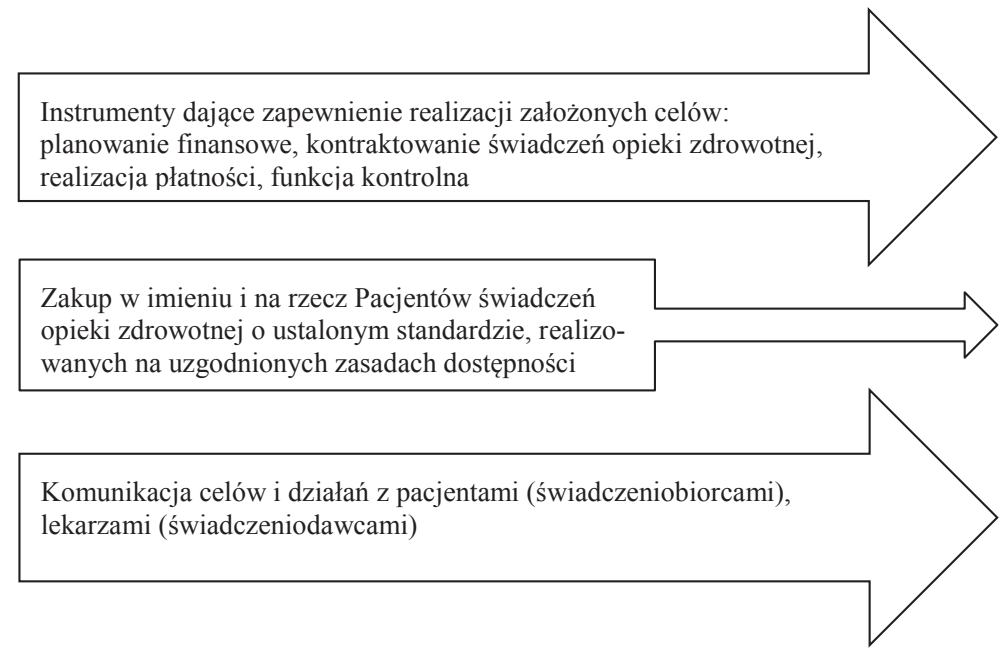

\section{Rysunek 3. Rola NFZ}

Źródło: opracowanie własne.

Jak podkreśla I. Rudawska, rolą płatnika trzeciej strony jest przejęcie finansowych zobowiązań pacjenta wobec dostawców świadczeń opieki zdrowotnej w sytuacji choroby pacjenta. W zamian pacjent jest zobowiązany do uiszczania płatności w formie i na zasadach wynikających z przyjętych rozwiązań prawnych. Takie rozwiązanie ma zminimalizować brak pewności u pacjenta, że w momencie zachorowania, będzie mógł samodzielnie uregulować koszty leczenia (Rudawska, 2007, s. 21).

O zawarcie umowy o udzielanie świadczeń opieki zdrowotnej z NFZ mogą się ubiegać wyłącznie podmioty, które są „świadczeniodawcami”.

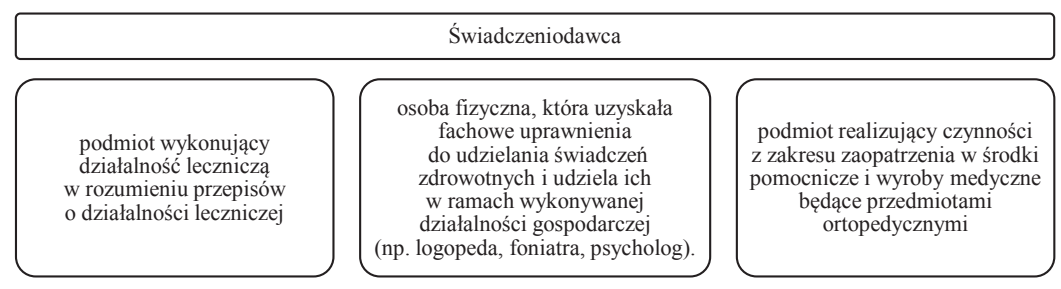

Rysunek 4. Zakres pojęcia „świadczeniodawca”

Źródło: opracowanie własne na podstawie Ustawa (2004).

Na potrzeby niniejszych rozważań Autor zawęził pojęcie pacjenta do katalogu osób określanych mianem „świadczeniobiorców”. 


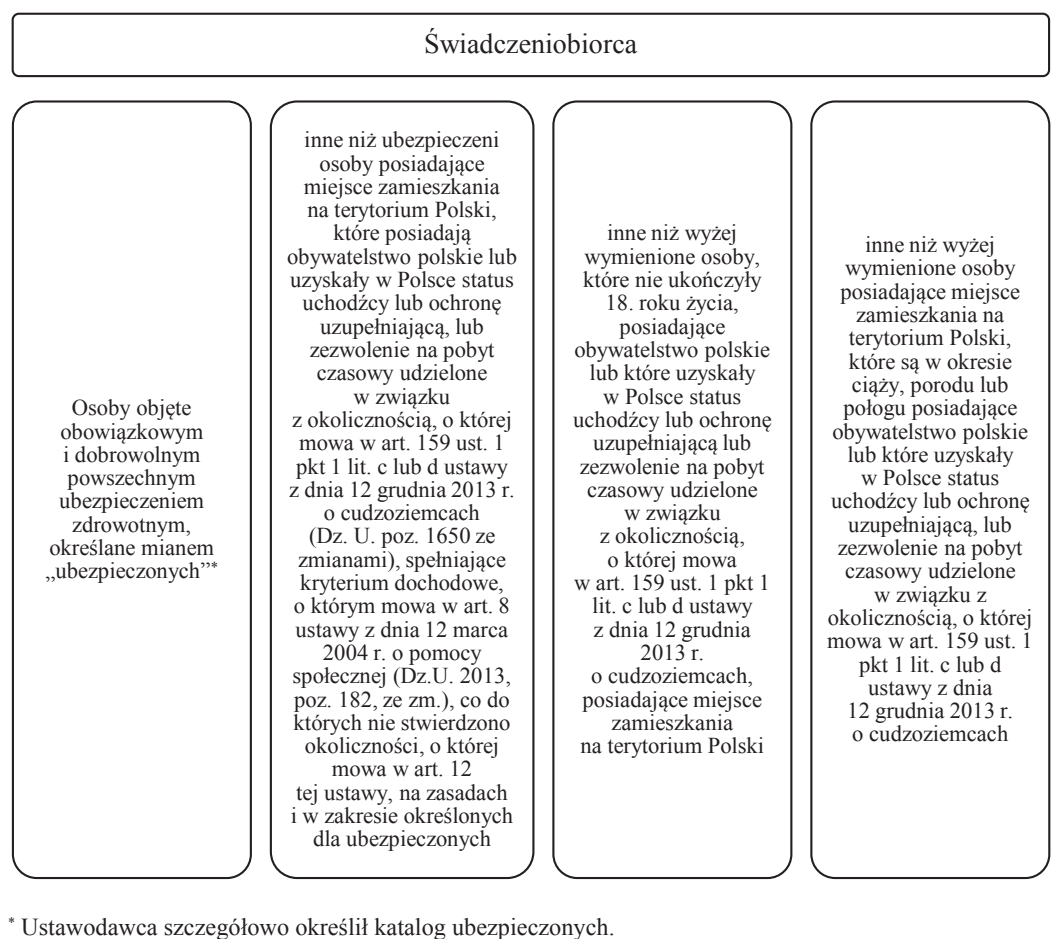

Rysunek 5. Zakres pojęcia „świadczeniobiorca”

Źródło: opracowanie własne na podstawie Ustawa (2004).

\section{Zaufanie jako podstawa budowania relacji w ochronie zdrowia}

Zaufanie ma szczególne znaczenie w warunkach zmiennego i trudno przewidywanego otoczenia. Dlatego w ochronie zdrowia stanowi realną wartość dodaną.

Modelowa sytuacja w „trójkącie relacji” to taka, kiedy pacjenci (świadczeniobiorcy) i lekarze (świadczeniodawcy) mają zaufanie do płatnika trzeciej strony. W praktyce oznacza to faktyczne przekonanie, że płatnik trzeciej strony działa „na rzecz i w interesie” (zob. Realizacja..., 2015, s. 53) pacjenta (świadczeniobiorcy) we współpracy z lekarzem (świadczeniodawcą).

Z dostępnych badań wynika, że dwie trzecie Polaków krytykuje funkcjonowanie NFZ, a tylko jedna czwarta ocenia go pozytywnie (Oceny..., 2017, s. 8). Wśród lekarzy ${ }^{2} 78 \%$ ocenia NFZ „zdecydowanie negatywnie” albo „raczej negatywnie”. Aż 69\% badanych oceniło negatywnie sposób informowania lekarzy przez NFZ o zarządzeniach, komunikatach,

\footnotetext{
${ }^{2}$ Badanie przeprowadzone na ogólnopolskiej reprezentatywnej próbie lekarzy i lekarzy dentystów.
} 
decyzjach i postanowieniach. Najczęściej negatywnie oceniano częstość i liczbę zmian zarządzeń, komunikatów, decyzji i postanowień, język aktów oraz terminowość przekazywania lekarzom ważnych informacji. Lekarze ocenili, że NFZ źle służy pacjentom (Krajewski, Perendyk, Wojtaszczyk).

W literaturze przedmiotu podkreśla się, że zaufanie to stały element każdej „,satysfakcjonującej relacji”. Można je zdefiniować jako przekonanie, że interesariusze będą działać dla wspólnych korzyści oraz że żadna ze stron nie będzie działać na szkodę drugiej strony (Krot, Rudawska, 2013, s. 382). Zaufanie wiąże się z oczekiwaniem, że ten, którego obdarzamy zaufaniem, „spełni pewne kryteria” (Królik, 2015, s. 72). W odniesieniu do ochrony zdrowia zaufanie może być rozpatrywane jako zaufanie interpersonalne i zaufanie społeczne, czyli obejmujące różne instytucje i ich wzajemne relacje, rozwiązania prawne, system jako całość (Lewandowski, 2011, s. 90). Warto odnotować opinię, że „,współczesne przemiany w medycynie i opiece zdrowotnej utrudniają zaufanie" (Głos, 2015, 83).

Autor jest przekonany, że do budowania relacji w ochronie zdrowia na zaufaniu, konieczna jest życzliwość i uczciwość. Tym samym nie ma miejsca na wzajemną podejrzliwość. Kolejny element budujący zaufanie to przewidywalność, czyli strony muszą być dla siebie przewidywalne w działaniu. Istotne są też kompetencje stron. Muszą się one wzajemnie nauczyć elementów roli społecznej drugiej strony, poznać wzajemne prawa, obowiązki i zadania oraz wynikające z tego możliwości i ograniczenia. Dopiero wówczas strony mogą zdefiniować adekwatne do tej wiedzy oczekiwania. Mogą dokonywać oceny postaw.

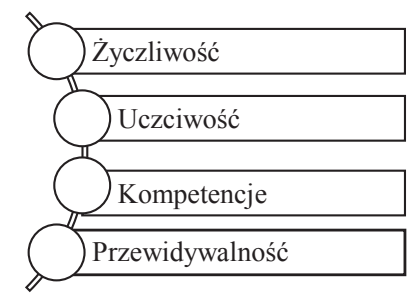

Rysunek 6. Najczęściej pojawiające się charakterystyki zaufania

Źródło: opracowanie własne na podstawie Miszczak (2016), s. 100.

Elementem zasadniczym omawianych relacji są uprawnienia przypisane pacjentowi (świadczeniobiorcy), które realizowane są w postaci zadań przypisanych płatnikowi trzeciej strony i lekarzom (świadczeniodawcom). Stanowią one punkt wyjścia do zdefiniowania zakresu przedmiotowego „trójkąta relacji”. Poniżej zaprezentowano obszary budowania relacji pacjent (świadczeniobiorca) - płatnik trzeciej strony (NFZ) - lekarz (świadczeniodawca). 


\section{Tabela 1}

Obszary budowania relacji pacjent (świadczeniobiorca)-płatnik trzeciej strony (NFZ)-lekarz (świadczeniodawca)

\begin{tabular}{|c|c|c|}
\hline Pacjent (świadczeniobiorca) & Płatnik trzeciej strony (NFZ) & Lekarz (świadczeniodawca) \\
\hline 1 & 2 & 3 \\
\hline \multicolumn{3}{|c|}{ Dostęp do odpowiednich świadczeń opieki zdrowotnej } \\
\hline $\begin{array}{l}\text { podstawa prawna: } \\
\text { - ustawa o świadczeniach } \\
\text { opieki zdrowotnej finansowa- } \\
\text { nych ze środków publicz- } \\
\text { nych - art. } 15 \text {, } \\
\text { - ogólne warunki umów } \\
\text { o udzielanie świadczeń opie- } \\
\text { ki zdrowotnej - } 33, \S 7-8\end{array}$ & $\begin{array}{l}\text { podpisanie umów o udzie- } \\
\text { lanie świadczeń opieki } \\
\text { zdrowotnej z podmiotami } \\
\text { spełniającymi określone } \\
\text { wymogi dotyczące m.in. } \\
\text { wyposażenia oraz kwalifika- } \\
\text { cji i ilości personelu, } \\
\text { - weryfikacja i kontrola prze- } \\
\text { strzegania przez świadcze- } \\
\text { niodawców prawa }\end{array}$ & $\begin{array}{l}\text { - udzielanie świadczeń opieki zdrowotnej } \\
\text { z zachowaniem należytej staranności oraz } \\
\text { przy poszanowaniu praw pacjenta, } \\
\text { — udzielenie świadczenia opieki zdrowotnej } \\
\text { w pomieszczeniach odpowiadających } \\
\text { określonym przepisom, przy wykorzysta- } \\
\text { niu aparatury i sprzętu medycznego posia- } \\
\text { dającego stosowne certyfikaty i atesty, } \\
\text { - udzielenia świadczeń opieki zdrowotnej } \\
\text { w sposób kompleksowy obejmujący wy- } \\
\text { konanie niezbędnych badań, w tym badań } \\
\text { laboratoryjnych i diagnostyki obrazowej } \\
\text { oraz procedur medycznych }\end{array}$ \\
\hline \multicolumn{3}{|l|}{ Wybór świadczeniodawcy } \\
\hline $\begin{array}{l}\text { podstawa prawna: } \\
\text { - ustawa o świadczeniach } \\
\text { opieki zdrowotnej finansowa- } \\
\text { nych ze środków publicz- } \\
\text { nych - art. } 29 \text { - } 31 \text {, } \\
\text { - ustawa o podstawowej opie- } \\
\text { ce zdrowotnej - art. } 9\end{array}$ & $\begin{array}{l}\text { - zakontraktowanie świadczeń } \\
\text { opieki zdrowotnej w sposób } \\
\text { zapewniający odpowiednią } \\
\text { dostępność do świadczeń } \\
\text { danego rodzaju, } \\
\text { - weryfikacja i kontrola prze- } \\
\text { strzegania przez świadcze- } \\
\text { niodawców prawa }\end{array}$ & $\begin{array}{l}\text { - udzielanie świadczeń opieki zdrowotnej } \\
\text { wszystkim świadczeniobiorcom, niezależ- } \\
\text { nie od miejsca ich zamieszkania, } \\
\text { - zapewnienie badań laboratoryjnych i dia- } \\
\text { gnostyki obrazowej w ramach udzielanej } \\
\text { porady lub przy współpracy z podwyko- } \\
\text { nawcą, } \\
\text { - przyjmowanie deklaracji wyboru lekarza, } \\
\text { pielęgniarki lub położnej podstawowej } \\
\text { opieki zdrowotnej }\end{array}$ \\
\hline \multicolumn{3}{|l|}{ Uzyskanie zaświadczenia } \\
\hline $\begin{array}{l}\text { podstawa prawna: } \\
\text { - ustawa o świadczeniach } \\
\text { opieki zdrowotnej finansowa- } \\
\text { nych ze środków publicz- } \\
\text { nych - art. } 16\end{array}$ & $\begin{array}{l}\text { - kontrola i weryfikacja prze- } \\
\text { strzegania przez świadcze- } \\
\text { niodawców prawa }\end{array}$ & $\begin{array}{l}\text { - wystawianie bezpłatnych orzeczeń } \\
\text { i zaświadczeń lekarskich określonych } \\
\text { w przepisach, } \\
\text { - współpraca z podmiotami zlecającymi } \\
\text { wydanie orzeczeń lub zaświadczeń finan- } \\
\text { sowanych przez te podmioty }\end{array}$ \\
\hline \multicolumn{3}{|c|}{ Dostęp do świadczeń w określonym czasie } \\
\hline $\begin{array}{l}\text { podstawa prawna: } \\
\text { - ustawa o świadczeniach } \\
\text { opieki zdrowotnej finansowa- } \\
\text { nych ze środków publicz- } \\
\text { nych - rozdz. 3, } \\
\text { - rozporządzenie Ministra } \\
\text { Zdrowia w sprawie kryteriów } \\
\text { medycznych, jakimi powinni } \\
\text { kierować się świadczenio- } \\
\text { dawcy umieszczając świad- } \\
\text { czeniobiorców na listach } \\
\text { oczekujących na udzielenie } \\
\text { świadczenia opieki zdro- } \\
\text { wotnej, }\end{array}$ & $\begin{array}{l}\text { - zakontraktowanie świadczeń } \\
\text { opieki zdrowotnej w sposób } \\
\text { zapewniający odpowiednią } \\
\text { dostępność do świadczeń } \\
\text { danego rodzaju, } \\
\text { - monitoring list oczekujących } \\
\text { prowadzonych przez świad- } \\
\text { czeniodawców, } \\
\text { - informowanie świadczenio- } \\
\text { biorców o liczbie ocze- } \\
\text { kujących, średnim czasie } \\
\text { oczekiwania oraz pierwszym } \\
\text { wolnym terminie udzielenia } \\
\text { świadczenia, }\end{array}$ & $\begin{array}{l}\text { - zapewnienie sprawiedliwego, równego, } \\
\text { niedyskryminującego i przejrzystego } \\
\text { dostępu do świadczeń opieki zdrowotnej, } \\
\text { - prowadzenie list oczekujących na udzie- } \\
\text { lenie świadczenia opieki zdrowotnej oraz } \\
\text { sprawozdawanie tych informacji do NFZ, } \\
\text { - kwalifikacja pacjentów do kategorii me- } \\
\text { dycznej ,przypadek pilny” lub „przypa- } \\
\text { dek stabilny”, } \\
\text { - przyjmowanie świadczeniobiorców kon- } \\
\text { tynuujących leczenie zgodnie z planem } \\
\text { leczenia, } \\
\text { - okresowa kontrola list oczekujących, }\end{array}$ \\
\hline
\end{tabular}




\begin{tabular}{|c|c|c|}
\hline 1 & 2 & 3 \\
\hline $\begin{array}{l}\text { - ogólne warunki umów } \\
\text { o udzielanie świadczeń opie- } \\
\text { ki zdrowotnej - § } 13\end{array}$ & $\begin{array}{l}\text { - informowanie świadczenio- } \\
\text { biorców wpisanych na listę } \\
\text { oczekujących u świadczenio- } \\
\text { dawców, którzy zakończyli } \\
\text { wykonywanie umowy } \\
\text { o możliwości skorzystania ze } \\
\text { świadczeń u innych świad- } \\
\text { czeniodawców, } \\
\text { - weryfikacja i kontrola prze- } \\
\text { strzegania przez świadcze- } \\
\text { niodawców prawa }\end{array}$ & $\begin{array}{l}\text { - informowanie świadczeniobiorców w każ- } \\
\text { dy możliwy sposób o zmianie terminu } \\
\text { udzielenia świadczenia, } \\
\text { - respektowanie praw do udzielenia świad- } \\
\text { czeń poza kolejnością grupom świadcze- } \\
\text { niobiorców wymienionym w przepisach, } \\
\text { - zapewnienie rejestracji czynnej każdego } \\
\text { dnia w godzinach udzielania świadczeń } \\
\text { opieki zdrowotnej }\end{array}$ \\
\hline
\end{tabular}

Bezpłatne zaopatrzenie w leki i wyroby medyczne podczas pobytu w szpitalu

\begin{tabular}{|c|c|c|}
\hline $\begin{array}{l}\text { podstawa prawna: } \\
\text { - ustawa o świadczeniach } \\
\text { opieki zdrowotnej finansowa- } \\
\text { nych ze środków publicz- } \\
\text { nych - art. } 35 \\
\end{array}$ & $\begin{array}{l}\text { - weryfikacja i kontrola prze- } \\
\text { strzegania przez świadcze- } \\
\text { niodawców prawa }\end{array}$ & $\begin{array}{l}\text { - zapewnienie bezpłatnych leków, środków } \\
\text { spożywczych specjalnego przeznaczenia } \\
\text { żywieniowego i wyrobów medycznych, } \\
\text { jeżeli są one konieczne do wykonania } \\
\text { świadczenia }\end{array}$ \\
\hline \multicolumn{3}{|c|}{ Przejazd środkami transportu sanitarnego } \\
\hline $\begin{array}{l}\text { podstawa prawna: } \\
\text { - ustawa o świadczeniach } \\
\text { opieki zdrowotnej finansowa- } \\
\text { nych ze środków publicz- } \\
\text { nych - art. } 41 \text {, } \\
\text { - ogólne warunki umów } \\
\text { o udzielanie świadczeń opie- } \\
\text { ki zdrowotnej - } § 8\end{array}$ & $\begin{array}{l}\text { - } \text { weryfikacja i akceptacja } \\
\text { wniosków o transport } \\
\text { sanitarny, } \\
\text { - weryfikacja i kontrola prze- } \\
\text { strzegania przez świadcze- } \\
\text { niodawców prawa }\end{array}$ & $\begin{array}{l}\text { - ocena stanu zdrowia świadczeniobior- } \\
\text { cy mająca na celu określenie prawa do } \\
\text { transportu bezpłatnego lub za częściową } \\
\text { odpłatnością, } \\
\text { - zapewnienie w ramach kompleksowości } \\
\text { udzielania świadczeń transportu sanitarne- } \\
\text { go w ramach kwoty określonej w umowie, } \\
\text { - zapewnienie transportu sanitarne- } \\
\text { go spełniającym określone wymogi } \\
\text { i w odpowiednim składzie osobowym lub } \\
\text { ustalonym z uwzględnieniem wskazań } \\
\text { medycznych i ciągłości udzielania świad- } \\
\text { czeń, gwarantującymi najkrótszy czas } \\
\text { transportu świadczeniobiorcy adekwatny } \\
\text { do jego stanu zdrowia }\end{array}$ \\
\hline
\end{tabular}

\begin{tabular}{|c|c|}
\hline Dostęp do informacji o udzielony & ych świadczeniach opieki zdrowotnej \\
\hline $\begin{array}{l}\text { podstawa prawna: } \\
\text { — ustawa o świadczeniach } \\
\text { opieki zdrowotnej finansowa- } \\
\text { nych ze środków publicz- } \\
\text { nych - art. 192, } \\
\text { - rozporządzenie Ministra } \\
\text { Zdrowia w sprawie sposobu, } \\
\text { trybu i terminów występowa- } \\
\text { nia do Narodowego Fundu- } \\
\text { szu Zdrowia oraz udostępnia- } \\
\text { nia przez Narodowy Fundusz } \\
\text { Zdrowia świadczeniobiorcy } \\
\text { informacji o prawie do } \\
\text { świadczeń opieki zdrowot- } \\
\text { nej oraz o udzielonych mu } \\
\text { świadczeniach }\end{array}$ & $\begin{array}{l}\text { - na żądanie świadczenio- } \\
\text { biorcy udzielanie pisemnej } \\
\text { informacji o udzielonych } \\
\text { mu świadczeniach opieki } \\
\text { zdrowotnej, } \\
\text { - wydawanie danych dostę- } \\
\text { powych do Zintegrowanego } \\
\text { Informatora Pacjenta }\end{array}$ \\
\hline
\end{tabular}

Źródło: opracowanie własne na podstawie aktów prawnych. 
Stopień realizacji wymienionych uprawnień jest niczym innym, jak swoistym sprzężeniem zwrotnym w „trójkącie relacji”. Istotnym źródłem informacji w tym zakresie są skargi składane przez pacjentów (świadczeniobiorców). Ilość i treść składanych skarg obrazują poziom satysfakcji pacjentów (świadczeniobiorców). To z kolei determinuje poziom zaufania w ,trójkącie relacji”.

W roku 2017 LOW NFZ rozpatrzył 250 skarg, z tego 80 uznano za zasadne, 31 uznano za niezasadne, a 139 zakwalifikowano jako częściowo zasadne. Najwięcej skarg złożono w rodzaju ,ambulatoryjna opieka specjalistyczna”, ,podstawowa opieka zdrowotna” i ,leczenie szpitalne".

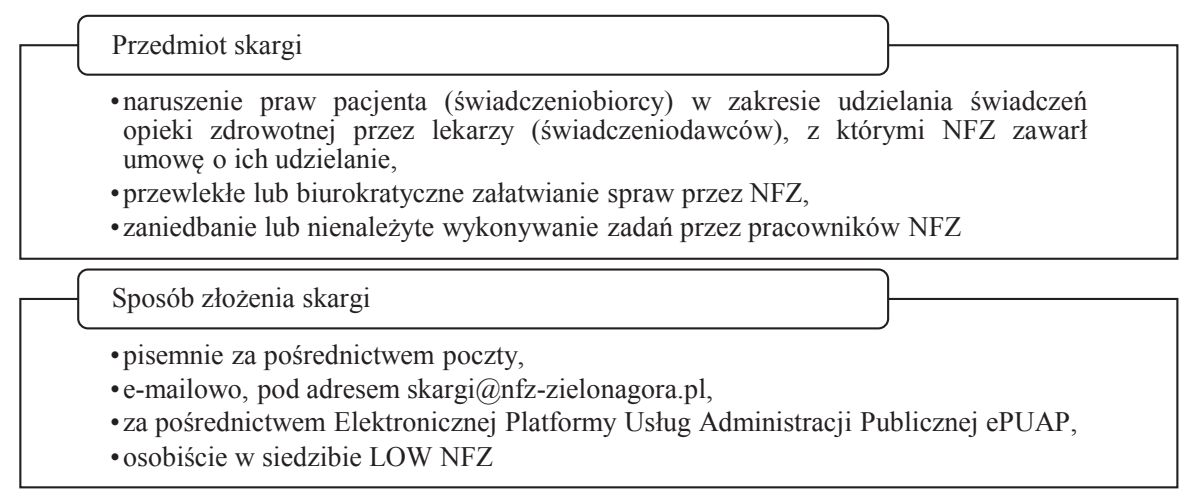

Rysunek 7. Przedmiot i sposoby przyjmowania skarg

Źródło: opracowanie własne na podstawie Zarządzenia Prezesa Narodowego Funduszu Zdrowia (2015).

Dominowały skargi dotyczące odmowy udzielenia świadczeń opieki zdrowotnej, odmowy wydania skierowania, pobierania opłat za świadczenia opieki zdrowotnej, zastrzeżeń do toku leczenia, jakości udzielonych świadczeń opieki zdrowotnej, złej organizacji pracy lekarza (świadczeniodawcy), niewłaściwej obsługi w rejestracji i funkcjonowania systemu ochrony zdrowia.

Tylko 10 skarg dotyczyło bezpośrednio działalności LOW NFZ. 


\section{Formy komunikacji i działania poprawiające jakość obsługi na przykładzie LOW NFZ}

Ważnym elementem budowania zaufania w ochronie zdrowia jest jakość obsługi i komunikacja. Liczy się dobór słów, ich zrozumienie u odbiorcy. Nie wystarczy odesłać lekarza, pacjenta do konkretnego zapisu ustawy, rozporządzenia lub zarządzenia. Nie wystarczy wydać poprawnej z punktu widzenia formalnoprawnego decyzji administracyjnej nakładającej na pacjenta obowiązek zwrotu kosztów leczenia. Nie wystarczy powiedzieć „nie ma pieniędzy”, „nie ma lekarzy”, „to wina systemu informatycznego”. Nie wystarczy „mieć racji”. Nie w ochronie zdrowia. W tym przypadku istotna jest zarówno satysfakcja z jakości obsługi, jak i poziom wiedzy o możliwościach uzyskania wsparcia. Dlatego LOW NFZ wykorzystuje różnorodne formy komunikacji. Podejmuje też działania mające na celu podniesienie jakości obsługi.

Katalog działań w tym zakresie zaprezentowano poniżej.

\begin{tabular}{|c|}
\hline Strona internetowa \\
\hline $\begin{array}{l}\text { - serwis internetowy, zawierający aktualności i najważniejsze informacje } \\
\text { kierowane do lekarzy (świadczeniodawców) i farmaceutów. W serwisie jest } \\
\text { również dostępny informator o postępowaniach na udzielanie świadczeń } \\
\text { opieki zdrowotnej refundowanych przez LOW NFZ }\end{array}$ \\
\hline Portal Świadczeniodawcy \\
\hline $\begin{array}{l}\text { - platforma wymiany informacji pomiędzy NFZ a lekarzami } \\
\text { (świadczeniodawcami) }\end{array}$ \\
\hline Współpraca z organizacjami zrzeszającymi zawody medyczne \\
\hline $\begin{array}{l}\text { •współpraca z Federacją Związków Pracodawców Ochrony Zdrowia } \\
\text { Porozumienie Zielonogórskie, Okręgową Izbą Lekarską w Zielonej Górze } \\
\text { i Gorzowie Wielkopolskim, Okręgową Izbą Pielęgniarek i Położnych } \\
\text { w Zielonej Górze i Gorzowie Wielkopolskim }\end{array}$ \\
\hline
\end{tabular}

Rysunek 8. Formy komunikacji LOW NFZ - lekarz (świadczeniodawca)

Źródło: opracowanie własne na podstawie danych LOW NFZ. 


\begin{tabular}{|c|}
\hline Strona internetowa \\
\hline $\begin{array}{l}\text { - serwis internetowy, zawierający najważniejsze i bieżące informacje dotyczące } \\
\text { działalności LOW NFZ, w tym ABC pacjenta, aktualności i informator o zasadach } \\
\text { korzystania z opieki zdrowotnej; utworzona zastała też specjalna zakładka "Zdrowie } \\
\text { mężczyzn", a w planach jest utworzenie zakładki "Zdrowie Seniora"; w serwisie jest } \\
\text { również dostępny informator "Gdzie się leczyć", zawierający wykaz wszystkich } \\
\text { podmiotów medycznych świadczących usługi zdrowotne, informacje dotyczące } \\
\text { profilaktycznych programów zdrowotnych, harmonogramy dotyczące stacjonowania } \\
\text { mammobusów }\end{array}$ \\
\hline Infolinia \\
\hline $\begin{array}{l}\text { - całodobowa możliwość uzyskania telefonicznej informacji na temat danych } \\
\text { teleadresowych świadczeniodawców, zasad korzystania z podstawowej opieki } \\
\text { zdrowotnej, zasad i miejsc udzielania pomocy medycznej w nocy i w dni wolne, } \\
\text { zasad udzielania świadczeń zdrowotnych i funkcjonowania powszechnego } \\
\text { ubezpieczenia zdrowotnego, dokumentów potwierdzających prawo do świadczeń, } \\
\text { systemu e-WUŚ, systemu ZIP, wysokości składki zdrowotnej, wydania EKU, } \\
\text { zasad koordynacji systemów zabezpieczenia zdrowotnego w krajach Unii } \\
\text { Europejskiej, zasad korzystania z profilaktycznych programów zdrowotnych }\end{array}$ \\
\hline Zintegrowany Informator Pacjenta \\
\hline $\begin{array}{l}\text { - ogólnopolski serwis umożliwiający pacjentom szybki dostęp do informacji o prawie } \\
\text { do świadczeń opieki zdrowotnej, udzielonych świadczeniach, przepisanych lekach } \\
\text { oraz kwotach przekazanych na sfinansowanie leczenia }\end{array}$ \\
\hline Ogólnopolski Informator o Czasie Oczekiwania na Świadczenia Medyczne \\
\hline $\begin{array}{l}\text { - serwis zawierający wykaz wszystkich placówek medycznych posiadających umowe } \\
\text { z NFZ na terenie całego kraju; pacjent ma możliwość uzyskania informacji } \\
\text { dotyczącej ilości osób oczekujących na świadczenia medyczne w poradniach } \\
\text { i oddziałach szpitalnych oraz o pierwszym wolnym terminie udzielenia świadczenia }\end{array}$ \\
\hline Informator medyczny \\
\hline $\begin{array}{l}\text { - bezpłatny poradnik zawierający najważniejsze informacje dotyczące systemu opieki } \\
\text { zdrowotnej oraz podmiotów, które zawarły umowę z LOW NFZ; publikacja } \\
\text { dedykowana specjalnie dla pacjentów w formie papierowej oraz PDF do pobrania na } \\
\text { stronie internetowej }\end{array}$ \\
\hline Współpraca z mediami \\
\hline $\begin{array}{l}\text { - konferencje prasowe, przekazywanie informacji oraz komunikatów prasowych } \\
\text { dotyczących działalności LOW NFZ, udział ekspertów LOW NFZ w programach } \\
\text { radiowych i telewizyjnych }\end{array}$ \\
\hline Współpraca z organizacjami pacjenckimi \\
\hline - wsparcie organizacji pacjenckich w ich działalności statutowej \\
\hline Akcje cykliczne \\
\hline $\begin{array}{l}\text { • coroczna debata ekspercka, konkurs plastyczny dla dzieci, konkurs dla dziennikarzy, } \\
\text { akcja "Święty Mikołaj" propagująca profilaktykę raka szyjki macicy i profilaktykę } \\
\text { raka piersi, akcja "Dzień Dziecka z LOW NFZ" }\end{array}$ \\
\hline
\end{tabular}

\section{Rysunek 9. Formy komunikacja LOW NFZ - pacjent (świadczeniobiorca)}

Źródło: opracowanie własne na podstawie danych LOW NFZ. 




Rysunek 10. Działania LOW NFZ mające na celu podniesienie jakości obsługi

Źródło: opracowanie własne na podstawie danych LOW NFZ.

\section{Uwagi końcowe}

Nie wszystko w ochronie zdrowia da się spersonalizować, skoordynować, zoptymalizować, „podstawić do wzoru”. Zdaniem autora świadome kształtowanie relacji w ochronie zdrowia wymaga działań ukierunkowanych na budowanie zaufania. Jednym z narzędzi, jakie można wykorzystać w tym zakresie, jest komunikacja, szczególnie ustawiczne, bezpośrednie interakcje. Dobrym krokiem w tym kierunku jest zainaugurowanie narodowej debaty o zdrowiu (Wspólnie..., 2018) pod warunkiem, że rozmówcy nie ulegną powszechnemu przekonaniu, o którym pisała A. Ostrowska, że poprawa i uzdrowienie finansów w ochronie zdrowia, „zniesie automatycznie wszystkie inne problemy” (Ostrowska, 2006, s. 187). Należy pamiętać, że postawa pacjenta (świadczeniobiorcy) kształtowana jest w dużym stopniu przez lekarza (świadczeniodawcę), a nie da się zniwelować wszystkich „pól konfliktów” w relacji płatnik trzeciej strony - lekarz (świadczeniodawca) (Bromber, 2012, s. 97). Do tego dochodzą jeszcze emocje pacjenta (świadczeniobiorcy), często zagubienie, bezradność, czyli treści, które trudno zobiektywizować. 


\section{Literatura}

Bromber, P. (2012). Rozważania o efektywności i konkurencyjności płatnika trzeciej strony na przykładzie Narodowego Funduszu Zdrowia. Studia i Materiaty WZ UW, 1-2.

Czerska, I. (2016). Relacje lekarz-pacjent a wybrane teoretyczne modele relacji w kontekście dehumanizacji medycyny. Handel Wewnętrzny, 5.

Głos, A. (2015). Dwa modele zaufania w opiece zdrowotnej. Diametros, 45.

http://isap.sejm.gov.pl.

Krajewski, R., Perendyk, T., Wojtaszczyk, K. Postawy i opinie dotyczq̨ce NFZ.

Krot, K., Rudawska, I. (2013). Koncepcja zaufania w relacji lekarz-pacjent w świetle badań jakościowych. Polityki Europejskie, Finanse i Marketing, 10 (59).

Królik, G. (2015). Rola zaufania w relacjach interpersonalnych jako determinanta efektywności zespołu. Studia Ekonomiczne. Zeszyty Naukowe Uniwersytetu Ekonomicznego w Katowicach, 230.

Lewandowski, R.A. (2011). Zaufanie w ochronie zdrowia. Wspótczesne Zarządzanie, 1. Pobrano z: 8723.indexcopernicus.com/fulltxt.php?ICID=1063477 (10.05.2018).

Maciąg, A. (2008). Komunikacja interpersonalna a jakość świadczeń zdrowotnych. Istota relacji lekarz-pacjent w medycynie. Studia i Materialy $W Z U W, 1$.

Maciąg, A. (2011). Kulturowe uwarunkowania komunikacji interpersonalnej w relacjach lekarz-pacjent. Studies \& Proceedings of Polish Association for Knowledge Management, 55.

Miszczak, M. (2016) Budowanie zaufania w relacjach z klientami poprzez komunikowanie praktyk CSR. Studia Ekonomiczne. Zeszyty Naukowe Uniwersytetu Ekonomicznego w Katowicach, 283.

Nowakowska, E. (2015). Morfologia więzi relacyjnych w instytucjach służby zdrowia. Studia i Prace Wydziału Nauk Ekonomicznych i Zarządzania US, 39 (t. 2).

Nowina-Konopka, M. (2016). Komunikacja lekarza-pacjent. Teoria i praktyka. Kraków: Instytut Dziennikarstwa, Mediów i Komunikacji Społecznej Uniwersytet Jagielloński.

Oceny instytucji publicznych (2017). Komunikat z badań nr 32. Centrum Badania Opinii Społecznej. Pobrano z: https://www.cbos.pl/SPISKOM.POL/2017/K_032_17.PDF.

Ostrowska, A. (2006). Paternalizm czy partnerstwo? Relacje między pacjentami a lekarzami w Europie. W: $W$ środku Europy? Wyniki Europejskiego Sondażu Społecznego, red. H. Domański, A. Ostrowska, P.B. Sztabiński. Warszawa: Wydawnictwo IFIS PAN.

Realizacja zadań na rzecz pacjentów. Podsumowanie działań i wyzwania na przyszłość (2015). Narodowy Fundusz Zdrowia. Pobrano z: http://www.nfz.gov.pl/download/gfx/nfz/pl/defaultstronaopisowa/349/28/1/\%20www.nfz. gov.pl/.../nfz._realizacja_zadan_na_rzecz_pacjentow._podsumowanie_dzialan_i_wyzwania_na_przyszlosc.. pdf (9.05.2018).

Rozporządzenia Ministra Zdrowia. Ogólne warunki umów o udzielanie świadczeń opieki zdrowotnej. T.j. Dz.U. 2016, poz. 1146 ze zm.

Rozporządzenie Ministra Zdrowia w sprawie kryteriów medycznych jakimi powinni kierować się świadczeniodawcy umieszczając świadczeniobiorców na listach oczekujących na udzielenie świadczenia opieki zdrowotnej. Dz.U. 2005, nr 200, poz. 1661.

Rozporządzenie Ministra Zdrowia z dnia 4 grudnia 2017 r. w sprawie sposobu, trybu i terminów występowania do Narodowego Funduszu Zdrowia oraz udostępniania przez Narodowy Fundusz Zdrowia świadczeniobiorcy informacji o prawie do świadczeń opieki zdrowotnej oraz o udzielonych mu świadczeniach. Dz.U. 2017, poz. 2297.

Rudawska, I. (2007), Opieka zdrowotna, aspekty rynkowe i marketingowe. Warszawa: Wydawnictwo Naukowe PWN.

Szewczyk, K. (2009). O bezsensie i potrzebie konstruowania modeli relacji lekarz-pacjent. Krytyka Lekarska, 2-3.

Ustawa z dnia 12 grudnia 2013 r. o cudzoziemcach. Dz.U. poz. 1650 ze zm.

Ustawa z dnia 12 marca 2004 r. o pomocy społecznej. Dz.U. 2013. poz. 182 ze zm.

Ustawa z dnia 25 sierpnia 2006 r. o bezpieczeństwie żywności i żywienia. Dz.U. 2010, nr 136, poz. 914 ze zm.

Ustawa z dnia 27 października 2017 r. o podstawowej opiece zdrowotnej. Dz.U. poz. 2217.

Ustawa z dnia 27 sierpnia 2004 r. o świadczeniach opieki zdrowotnej finansowanych ze środków publicznych. T.j. Dz.U. 2008 nr 164, poz. 1027 ze zm.

Wspólnie dla zdrowia. Stuchamy, rozmawiamy, działamy (prezentacja) (2018). Warszawa: Ministerstwo Zdrowia.

Zarządzenie nr 33/2015/BP Prezesa Narodowego Funduszu Zdrowia z dnia 29 czerwca 2015 r. w sprawie ogłoszenia jednolitego tekstu zarządzenia Prezesa Narodowego Funduszu Zdrowia w sprawie rozpatrywania skarg i wniosków w Narodowym Funduszu Zdrowia. 


\section{PATIENT RELATION-PAYER-DOCTOR}

Abstract: Purpose - The author's intention is to emphasise the importance of relations between stakeholders in health care. Considerations are based on the relationships between patients (beneficiary), doctors (care provider) and the third-side payer. The author described them as the "relationship triangle" in health care in the context of trust concept.

Design/methodology - In this paper, according to the author's objectives, the literature of the subject, opinion polls results and complaints submitted by patients were reviewed.

Value/orginality - In this perspective many activities undertaken by the Lubuskie Ward of the National Health Fund (LOW NFZ) in the field of analysed relationship were presented.

Keywords: health care, trust, relationship, patients, doctors, National Health Fund

\section{Cytowanie}

Bromber, P. (2018). Relacja pacjent-płatnik-lekarz. Finanse, Rynki Finansowe, Ubezpieczenia, 2 (92), $443-455$. DOI: $10.18276 /$ frfu.2018.92-38. 